\title{
Effect of Packaging Materials, Storage Conditions on the Vitamin C and pH Value of Cashew Apple (Anacardium occidentale L.) Juice
}

\author{
Emelike Nkechi Juliet Tamuno, Ebere Caroline Onyedikachi* \\ Department of Food Science and Technology, Rivers State University of Science and Technology, Port Harcourt, Rivers State, Nigeria
}

Email address:

eberecaroline@yahoo.com (Ebere C. O.)

To cite this article:

Emelike Nkechi Juliet Tamuno, Ebere Caroline Onyedikachi. Effect of Packaging Materials, Storage Conditions on the Vitamin C and PH Value of Cashew Apple (Anacardium occidentale L.) Juice. Journal of Food and Nutrition Sciences. Vol. 3, No. 4, 2015 , pp. 160-165. doi: $10.11648 /$ j.jfns.20150304.14

\begin{abstract}
Cashew apple (Anacardium occidentale L.) juice was produced and pasteurized at $80^{\circ} \mathrm{C}$ for 15 min in a water bath. The juice was packaged in different packaging materials - green $(\mathrm{G})$, brown $(\mathrm{B})$, white $(\mathrm{W})$ bottles and polyethylene sachet $(\mathrm{S})$ in $200 \mathrm{ml}$ batches and stored for four months at room $\left(30 \pm 1^{\circ} \mathrm{C}\right)$ and refrigeration $\left(4^{\circ} \mathrm{C}\right)$ temperatures to study the effect of packaging materials on the vitamin $\mathrm{C}$ and $\mathrm{pH}$ of cashew-apple juice $(\mathrm{CAJ})$. There were significant differences $(\mathrm{p}<0.05)$ in the value of vitamin $\mathrm{C}(48 \mathrm{mg} / 100 \mathrm{ml}-159 \mathrm{mg} / 100 \mathrm{ml})$ and $\mathrm{pH}(5.0-6.2)$ of the juice stored at $30 \pm 1 \mathrm{oC}$ as compared with those stored at $4^{\circ} \mathrm{C}$.At the ambient temperature, the highest loss of Vitamin $\mathrm{C}$ was observed with samples $\mathrm{S}$ which ranged from (83 - 48), first to fourth month, respectively. This is still higher than $45 \mathrm{mg}$ daily adult recommendation. The colour of the bottles did not have significant effect on the loss of vitamin $\mathrm{C}$ as the values ranged between $169-128 \mathrm{mg} / 100 \mathrm{~g}(\mathrm{~W}), 187-130 \mathrm{mg} / 100 \mathrm{~g}(\mathrm{G}) \mathrm{and} 188$ $-132 \mathrm{mg} / 100 \mathrm{~g}(\mathrm{~B})$ for months one to four at refrigeration temperature. Samples B and $\mathrm{G}$ retained the $\mathrm{pH}$ value of the juice at refrigeration temperature compared with samples $\mathrm{W}$ and $\mathrm{S}$. Though significant reductions was observed in the values of Vitamin $\mathrm{C}$ as time of storage progressed, the retained values in this study were still high when compared with the vitamin $\mathrm{C}$ content of other fruits in their fresh state. Therefore, CAJ can conveniently be produced and stored in green and brown bottles for up to four months in the refrigeration temperature to retain its vitamin $\mathrm{C}$ content and $\mathrm{pH}$ value which is an indication of good quality product. CAJ could also be stored in polyethylene sachet but not more than two months while the fruits are in season to serve as a cheap source of fresh drink, vitamin $\mathrm{C}$ and to reduce the $90 \%$ wastage of cashew-apples in the orchard.
\end{abstract}

Keywords: Packaging Materials, Storage Conditions, Vitamin C, pH Value, Cashew-Apples, Juice

\section{Introduction}

Cashew tree (Anacardium occidentale L.) is a cash crop in Nigeria. The cashew-apples are highly perishable not exceeding four days at room temperature [1]. Its availability is seasonal and even when in season, a large quantity of the apples are wasted due to lack of adequate storage facilities. To prevent wastage, add variety to the diet of the farmers and rural dwellers as well as increase their income, the apples can be converted to juice, marmalade, jam and wine [2].The study carried out at Cocoa Research Institute of Nigeria (CRIN) revealed that the present consumption of cashew-apples either in raw or processed form is about $10 \%$ of production [3].

According to Food and Agriculture Organization [4], the major component of fruits is water derived from the extra and intracellular fluids necessary for metabolic processes and maintenance of cell sugar. Water composition ranges from $97 \%$ in some wild barriers to $70 \%$ in over ripe grapes and less than $50 \%$ in fruits drying naturally on the plant. As a result of this, fruits and their juice are becoming an important part of the modern diet in many communities. They are nutritious and plays a significant role in a healthy diet because they offer good taste and a variety of nutrients found naturally in them. Fruit juices are fat-free, nutrient-dense beverages, rich in vitamins, minerals and naturally occurring phytonutrients that contribute to good health [5] and promote detoxification in the human body [6].

The ban on importation of fruits and drinks in Nigeria has made it imperative and more profitable to engage in the extraction of juice from raw fruits such as cashew-apples and 
other fruits and by extension, the preservation and packaging of the fruits with the objective of preserving the product for a longer time. Preserved fruit juice commands a higher value and can be consumed more conveniently than whole fruits [7, 8]. This has become the business activity of great significance. Countries with abundant fruit resources with short harvest season are focusing more on established storage facilities to maintain quality of fruits, increase their shelf life and preserve fruit juices for off-season [5].

To preserve, store and package fruit juices to increase its shelf life has led many researchers to carry out work on different fruits. Francis and Elizabeth [9] studied ascorbic acid retention in canned lime juice preserved with sulphur dioxide and benzoic acid. The role of sodium benzoate as a chemical preservative in extending the shelf life of orange juice was done by Muhammad et al.,[10] while the effects of packaging materials, storage temperature and time on roselle-mango juice blends was carried out by Mgaya-Kilima et al., [11]. All these were a means of preserving fruits during its off-season.

Cashew-apple juice is a valuable source of water, minerals and rich in vitamin $C$ [12]. It is reported to contain five times as much vitamin $\mathrm{C}$ as citrus juice [13] and ten times as pineapple juice [14]. De Carvalho et al., [15] also reported that cashew-apple juice has the potential to be a natural source of vitamin $\mathrm{C}$ and sugar in the processed foods. Vitamin $\mathrm{C}$ in fruits plays important role in utilization of amino acid tyrosine, lipid metabolism and collagen formation [16].Vitamin C content of fruit juices degrades over time in freshly squeezed juice. According to Nagy et al., [17], temperature and storage time affects the percentage of vitamin $\mathrm{C}$ in orange fruits as well as other fruit juices.

Packaging is an important aspect in the food processing industry as it serves the important functions of containing the food, protecting against chemical and physical damage while providing information on product features, nutritional status and ingredient information [18]. Various packaging materials such as high-density polyethylene (HDPE), polypropylene (PP), metal cans and glass are commonly used for packaging of fruit juices [19]. In order to facilitate preservation, it is a technological practice to package juices in these materials. Although, metal cans are expensive and require sophisticated machinery for container closure [20]. They have been shown to effect ascorbic acid retention better than other packaging materials [21].

Processing of cashew-apples to produce fruit juice and to preserve it for use at off-season is the objective of the present study. The focus of this work is to evaluate the effect of different coloured packaging materials, storage conditions on the vitamin $\mathrm{C}$ retention and $\mathrm{pH}$ value in order to know how best and long cashew-apple juice (CAJ) could be stored.

\section{Materials and Methods}

\subsection{Materials}

Mature, ripe cashew-apples (Anacardium occidentale L.), red and yellow varieties were harvested in an orchard at Uturu,
Abia State, Nigeria. A total of hundred kilograms of fruits were utilized.

Bottles of different colours such as white, green, brown and high-density polyethylene sachets were purchased from Next-time Supermarket, Port Harcourt, Rivers State, Nigeria.

\subsection{Methods}

The fruits (cashew-apples) were sorted to remove the rotten ones, deseeded, weighed and washed in running water. Average weight of the apples was $35 \pm 3.5 \mathrm{~g}$ and average weight of the nuts was $4.5 \pm 0.9 \mathrm{~g}$.

The apples were allowed to drain off water after washing. They were sliced and blended using Sumeet Food Processor (Model A). The blended apples were then pressed to express the juice through muslin cloth folded into 2, 4 and 8 layers, respectively. The obtained juice $(200 \mathrm{ml}$ batches) were filled into ten bottles for each colour (white "W", green "G", brown "B") and high-density polyethylene sachets (S) and pasteurized at $80^{\circ} \mathrm{C}$ for $15 \mathrm{~min}$ in a water bath. The bottles were corked by means of capping machine, the sachets sealed using a heat sealer and cooled rapidly to room temperature by immersing them in cold water bath [22] then stored at $30 \pm 1^{\circ} \mathrm{C}$ and $4^{\circ} \mathrm{C}$ for a period of four months.

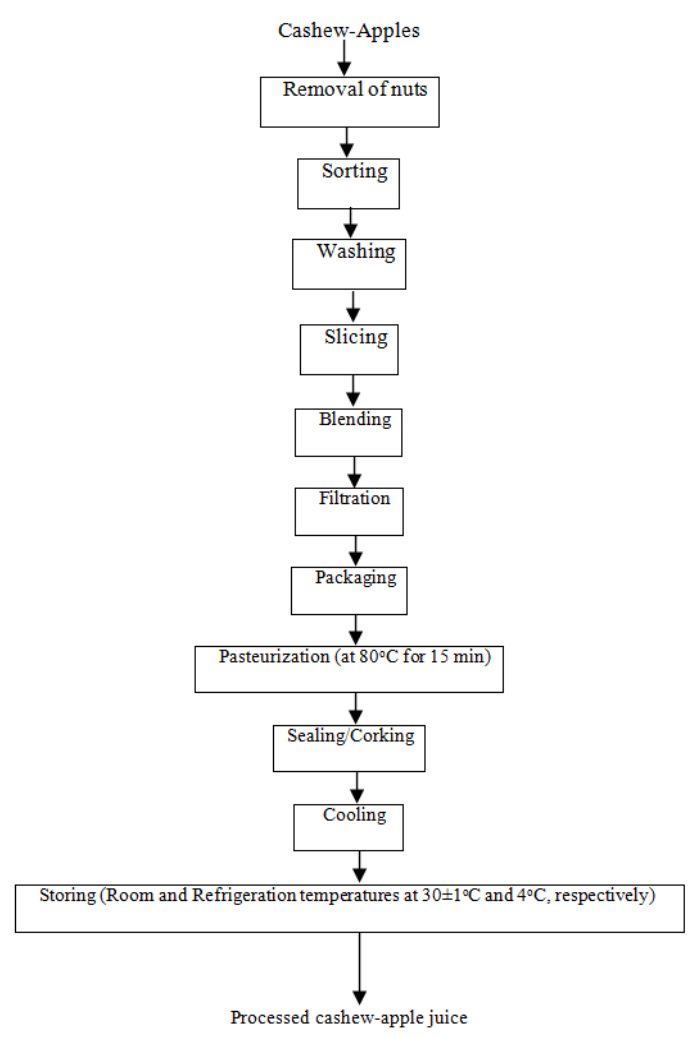

Figure 1. Simplified flow diagram of cashew-apple juice extraction.

Source: Authors' Computation.

\subsection{Analysis on Pasteurized CAJ.}

\subsubsection{Ascorbic Acid Determination}

Ascorbic acid is a water-soluble vitamin. It is vital to our 
body and can be found in various fruits and vegetables. Its determination has become increasingly important in areas such as pharmaceutical, clinical and food.

The ascorbic acid content of pasteurized CAJ and stored samples at different temperatures (Room and refrigeration) were determined using redox titration. Dye solution, 2,6-dichloroindophenol (DCIP) methods [23], was employed to titrate with the vitamin $\mathrm{C}$ in the extracted sample solution. The extracting solution was a mixture of metaphosphoic acid with $0.5 \%$ oxalic acid. The solution was used to stabilize the extracted vitamin $\mathrm{C}$ by preventing its oxidation. The DCIP served as the indicator as excess DCIP turned the solution pink after it was passed through the end point $25 \mathrm{ml}$ of the juice was used for each analysis.

Ascorbic acid mg/100ml juice $=20 \times(v) \times(c)$.

Where $\mathrm{V}=\mathrm{ml}$ indophenol solution in redox titration.

$\mathrm{C}=\mathrm{mg}$ vitamin $\mathrm{C} / \mathrm{ml}$ indophenol solution.

\subsubsection{PH Determination}

The $\mathrm{pH}$ of the pasteurized CAJ samples were determined using Gouras digital $\mathrm{pH}$ meter, standardized with buffer $\mathrm{pH}$ of 40 and 90 [23]. The meter was dipped into the juice contained in a beaker. The $\mathrm{pH}$ was determined before and weekly during storage for a period of four months. In each case, $10 \mathrm{ml}$ aliquots of samples were measured in triplicate and mean (averages) values recorded to represent a particular month.

\subsection{Statistical Analysis}

The data obtained were subjected to Analysis of Variance (ANOVA) using Statistical Package for Social Science (SPSS) version 20.0 software 2011. Significant means were differentiated using Turkey's text to establish significant differences among treatments

\section{Results and Discussions}

\subsection{Effect of Packaging Materials, Storage Conditions on the Vitamin Cof Cashew-Apple Juice Stored at Ambient and Refrigeration Temperature.}

Important requirements and functions of food packaging materials are that they should meet the aim of containing the food, protect against chemicals, physical damage, provide information on product features, nutritional status and ingredient information [18] as well as being inexpensive. The use of bottles in this study is due to the fact that bottle packaging is inexpensive and easy to cap as compared to metal cans that are expensive and require sophisticated machinery for container closure [20]. Polyethylene sachets are flexible and have perfect resistance to low temperature and impermeable to water vapour [24] and can be easily heat sealed.

There were reductions in the values of vitamin $\mathrm{C}$ in all the samples. The ranges of vitamin $\mathrm{C}$ from the first to the last month were; W (118 - 84), G (153 - 108), B (159-95) and S $(83-48)$, respectively, at ambient temperature as shown in Figure 2. Otta [25] stated that "prolonged storage causes a decrease in ascorbic acid content of fruit juices". Muhammad et al., [10] reported a significant effect in vitamin $\mathrm{C}$ content of orange juice using different packing bottles and storage periods. Mgaya-Kilima et al., [11] observed a decrease in the vitamin $\mathrm{C}$ content of roselle-mango juice blends stored over a period of time. Jawaheer et al., [26] also reported that vitamin $\mathrm{C}$ can easily be oxidized in the presence of oxygen by both enzymatic and non-enzymatic catalyst. The decrease was due to the labile nature of vitamin $\mathrm{C}$. it is worthy of note that the value of vitamin $\mathrm{C}$ retained in this study was still high when compared with the vitamin $\mathrm{C}$ content of other fruits in their fresh state; orange - $40 \mathrm{mh} / 100 \mathrm{~g}$, fresh tomatoes $24.08 \mathrm{mg} / 100 \mathrm{~g}$ [27]. At the ambient temperature, the vitamin $\mathrm{C}$ losses was higher in the juice stored with polyethylene (S) which ranged from (83 - 48), first to last month, respectively. Alaka et al., [28] also reported a decrease in vitamin $\mathrm{C}$ content of mango juice packaged in polyethylene films and stored at $6^{\circ} \mathrm{C}, 26^{\circ} \mathrm{C}$ and $34^{\circ} \mathrm{C}$. Despite the fact that loss of vitamin $\mathrm{C}$ in $\mathrm{CAJ}$ stored in polyethylene (S) in an ambient temperature is high, it still contained the recommended daily allowance (RDA) for adults, which is $45 \mathrm{mg}$ [29].

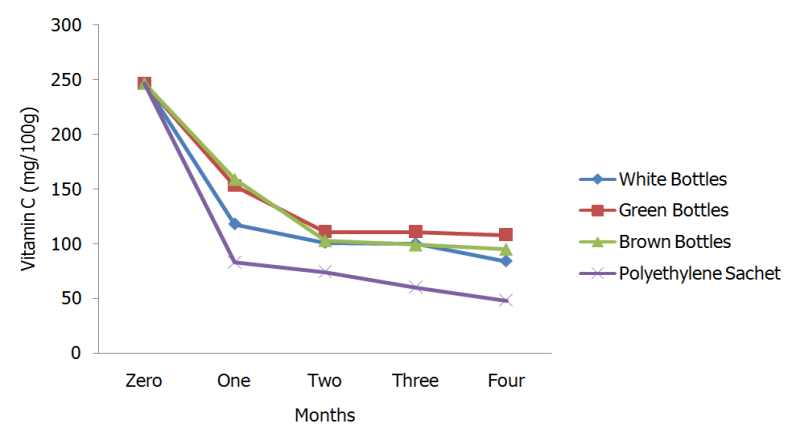

Figure 2. Effect of Packaging Materials on Vitamin $C$ of CAJ Stored at Ambient Temperature.

There were loss of vitamin C (247mg $-132 \mathrm{mg} / 100 \mathrm{~g})$ in the refrigerated samples but the values were less than the values lost at room temperature $(247 \mathrm{mg}-95 \mathrm{mg} / 100 \mathrm{~g})$. The ascorbic acid retention from first to last month were not significantly different $(\mathrm{p}>0.05)$ for samples $\mathrm{W}, \mathrm{G}$ and $\mathrm{B}$ as represented in Figure 3. The values were significantly different from the corresponding months for sample $\mathrm{S}$. This indicates that polyethylene (S) packaging material was not as effective in preserving vitamin $\mathrm{C}$ as the bottles. This is because light might have penetrated it causing vitamin $\mathrm{C}$ to leach out. The colour of the bottles did not have significant effect on the loss of vitamin $C$ as the values ranged between $169-128 \mathrm{mg} / 100 \mathrm{~g}$ (W), $187-130 \mathrm{mg} / 100 \mathrm{~g}(\mathrm{G})$ and $188-132 \mathrm{mg} / 100 \mathrm{~g}(\mathrm{~B})$ for months one to four. The general rule for fruits and fruit juices is low temperature storage.

Processing applied to the cashew juice resulted to $40-60 \%$ loss of ascorbic acid. Mgaya-Kilima et al., [11] reported 40\% loss of vitamin $\mathrm{C}$ content of roselle-mango juice blends. Polydera et al., [30] observed a decrease in vitamin $\mathrm{C}$ content of fruit juice stored over time. Jalil et al., [31] also reported that ascorbic acid decreased in all the samples studied. The decrease in vitamin $\mathrm{C}$ may be due to the oxidation and thermal 
degradation of ascorbic acid to dehydro - ascorbic acid. These losses were unavoidable due to the labile nature of vitamin $\mathrm{C}$ as mentioned earlier. The retained ascorbic acid values in the refrigeration temperature at the end of the fourth month are; $132 \mathrm{mg} / 100 \mathrm{~g}(\mathrm{~B})$ and $72 \mathrm{mg} / 100 \mathrm{~g}(\mathrm{~S})$ samples. These values were also high when compared to the values of other fruits: fresh orange $-72 \mathrm{mg} / 100 \mathrm{~g}$, pawpaw $-80 \mathrm{mg} / 100 \mathrm{~g}$, mango $57 \mathrm{mg} / 100 \mathrm{~g}$ [32]. Ahmed and Ramaswamy [33] stated that ascorbic acid loss is used as an indication of the extent of possible losses of other nutrients as well.

Bottle packaging and storage of CAJ for four months was effective in preserving its ascorbic acid. This agrees with the report of Ayhan et al., [34] who evaluated orange juice's aroma, colour and vitamin $\mathrm{C}$ in glass, PET, high/low-density polyethylene and found that packaging material has a significant effect on the retention of aroma, colour and vitamin $\mathrm{C}$ of orange juice and suggested bottle packaging.

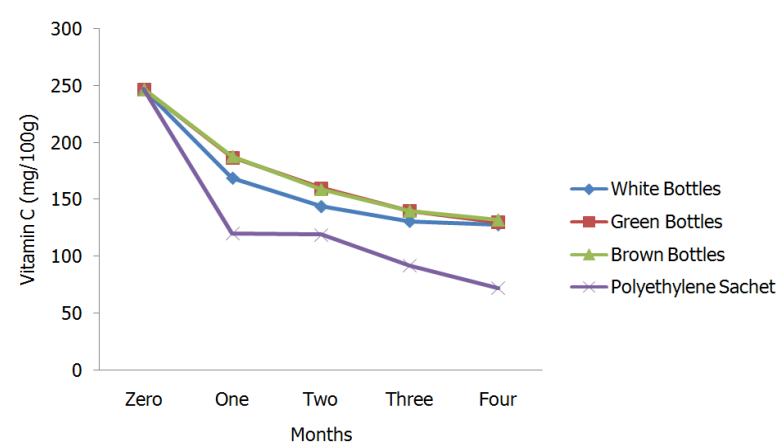

Figure 3. Effect of Packaging Materials on Vitamin C of CAJ Stored at Refrigeration Temperature.

\subsection{Effect of Packaging Materials and Storage Conditions on the pH of Cashew-Apple Juice Stored at Ambient and Refrigeration Temperatures.}

Measurement of $\mathrm{pH}$ is an index for determining food quality especially during storage. There was an increase in the $\mathrm{pH}$ of CAJ with time at room temperature. Mgaya-Kilima et al., [11] observed a similar increase in the value of $\mathrm{pH}$ of roselle-mango juice blends stored at different temperatures. The highest $\mathrm{pH}$ of 6.2 was observed in sample $\mathrm{S}$ at room temperature at fourth month as shown in Figure 4. There was no significant difference $(\mathrm{P}>0.05)$ between the $\mathrm{pH}$ values of the samples at the end of the third $(6.0,6.0,6.0,6.1)$ and fourth $(6.1,6.0,6.0,6.2)$ months for juice stored in $\mathrm{W}, \mathrm{G}, \mathrm{B}$ and $\mathrm{S}$, respectively. This may be due to protein denaturation at room temperature as reported by Chechin and Yamamoto [35] for pineapple juice. There was an increase in $\mathrm{pH}$ of sample $\mathrm{S}$ at the end of the second month at an ambient temperature when compared with W, G and B samples. This is because light and some gases might have penetrated the juice as polyethylene sachets have the disadvantage of being penetrable by gas, light and flavour [24]. It was time of storage not packaging materials that made slight significant differences in the $\mathrm{pH}$ of the juice stored in bottles at room temperature. Mgaya-Kilima et al., [11] reported that $\mathrm{pH}$ was affected by storage temperature and time. Muhammad et al., [10] also observed a non-significant effect of various packing bottles on $\mathrm{pH}$ of orange juice. This may be due to the fact that brown and green bottles shielded light from penetrating and causing oxidation as well as due to the inert nature of glass. Storage for about three to four months at ambient temperature significantly increased the $\mathrm{pH}$ of juice.

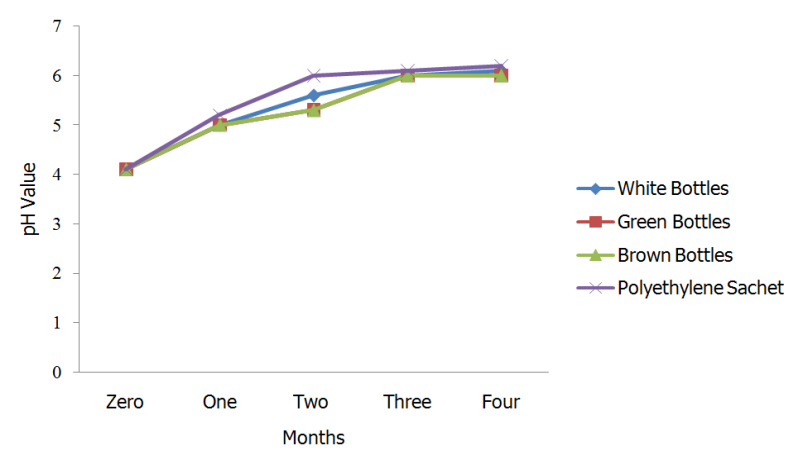

Figure 4. Effect of Packaging Materials on pH Value of CAJ Stored at Ambient Temperature.

At refrigeration temperature, after the slight increase at the end of the first month, there were no further significant increases in the $\mathrm{pH}$ value as represented in Figure 5. The increase in $\mathrm{pH}$ was uniform in all the packaging materials. The slight increase in the first month might have been caused by denaturation of some weak peptide bonds. The refrigeration temperature effectively checked further denaturation of protein. The packaging materials did not have significant effect at the fourth month at refrigeration temperature even for juice stored in polyethylene (S) as opposed to what happened at room temperature where significant difference was observed at the end of second month as compared to other packaging materials. This agrees with the findings of Mgaya-Kilima et al., [11]; Ihekeronye and Ngoddy [36] who recommended refrigeration storage as the best method for vegetables and fruits.

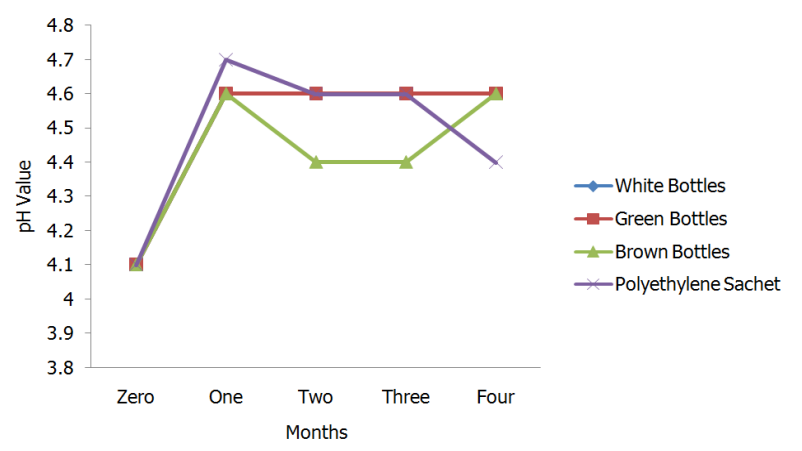

Figure 5. Effect of Packaging Materials on pH Value of CAJ Stored at Refrigeration Temperature.

\section{Conclusion}

The bottling process used in this study is a simulation of canning though not as effective because canning temperature 
is higher than that applied while bottling. The storage of CAJ in dark tinted bottles (Green and Brown) retained the vitamin $\mathrm{C}$ of the juice even at the end of the fourth month at $4^{\circ} \mathrm{C}$ and at the end of the second month at $30 \pm 1^{\circ} \mathrm{C}$ using white bottles and polyethylene sachets. It was observed that CAJ stored in polyethylene sachets was mostly affect. Yet, still meets up the daily recommended of Vitamin $\mathrm{C}$ intake for adults. Time and temperature of storage affected the $\mathrm{pH}$ of the juice and not packaging materials. The $\mathrm{pH}$ of the juice was best retained at refrigeration temperature. This is an indication that the quality of CAJ was retained at the refrigeration temperature throughout the period of the four months studied. Room temperature was not effective in preserving CAJ in all the packaging materials studied but green and brown bottles was observed to strive over time.

\section{References}

[1] Kristin, D. (1999). Cashew ECHO Technical Note. ECHO 17391 Durrance Road, North Ft. Meyers FL. 33917, U.S.A.

[2] Oduwole, O.O., Akinwale T.O. and Olubamiwa. O. (2001). Economic evaluation of a locally fabricated extraction machine for a cottage cashew juice factory. Journal of Food Technology of Africa. 6 (1); 18 - 20.

[3] Inyang, U.E. and Abah, U.J. (1997). Chemical composition and organoleptic evaluation of juice from steamed cashew apple blended with orange juice. Kluwer Academic Publishers. Printed in Netherlands. Plant foods for human nutrition, 50: 295-300.

[4] FAO (2001). Principles and practice of small and medium scale processing. FAO Agricultural bulletin, 146.

[5] Franke, A.A., Cooney, R.V., Henning, S.M. and Custer, L.J. (2005). Bioavailability and antioxidant effects of orange juice components in humans. Journal of Agricultural Food Chemistry, 53(13), 5170-5178.

[6] Deanna, M.M. and Bland, J.S. (2007). Acid-alkaline balance: role in chronic disease and detoxification. Alternative Therapies, 13(4), 62-65.

[7] Bates, E.C. and Swain, T. (2001). Flavonoid compounds. In: Comparative Biochemistry. (Eds) Mason, H.S. and Florkin, A.M. Academic Press N.Y. 755-809.

[8] Achal (2005). Cashew. Nutrition and Medical value. Colarado State University, 159-165.

[9] Francis, M.M. and Elizabeth, N.K. (2002). Ascorbic acid retention in canned lime juice preserved with sulphur dioxide and benzoic acid. African Journal of Food, Agriculture, Nutrition and Development, 2(1), 33-37.

[10] Muhammad, S., Saghir, A.S. and Saima, M. (2013). Role of sodium benzoate as a chemical preservative in extending the shelf life of orange juice. Global Advanced Research Journal of Food Science and Technology, 2(1), 007-018.

[11] Mgaya-Kilima, B., Remberg, S.F., Chove, B.E. and Wicklund, T. (2015). Physicochemical and antioxidant properties of roselle-mango juice blends; effects of packaging materials, storage temperature and time. Journal of Food Science and Nutrition, 3(2), 100-109.
[12] Azevedo, D.C.S. and Rodrigues, A. (2000). Obtainment of high-fructose solutions from cashew (Anacardium occidentale) apple juice by simulated moving-bed chromatography. Sep. Science and Technology, 35: 2561-2581.

[13] Akinwale, T. D. (2000) Cashew apple juice. "It's uses in fortifying the nutritional quality of some tropical fruits". European Food Research Technology, 211; 205 - 207.

[14] Ohler, J.G. (1988). Cashew. Communication. Department of Agricultural Research Institute Voor de Tropen, Amsterdam, 260.

[15] De Carvalho, J.M., Maia, G.A., de Figueiredo, R.W., de Brito, E.S. and Rodrigues, S. (2007). Development of a blended non-alcoholic beverage composed of coconut water and cashew apple juice containing caffeine. Journal of Food Quality, 30: 664-681.

[16] Hodges, E.E. (1974). Ascorbic acid in present knowledge in nutrition. (4th Ed). The nutrition foundation in U.S.A. 199-201.

[17] Nagy, Steven, Shaw, Philip, Wardowski and Wilfred, F. (1990). Fruits of tropical and sub-tropical origin: Composition; Properties and Uses. Florida Science Source, Inc.

[18] Anin, S.K., Ellis, W.O. and Adubofuor, J. (2010). Effects of two packaging materials and storage conditions on the quality of fresh taste, a natural and locally produced orange drink in Ghana. African Journal of Food Science and Technology, 1: 132-138.

[19] Marsh, K. and Bugusu, B. (2007). Food packaging-role, materials and environmental issues. Journal of Food Science, 72: $39-55$

[20] Griffin, R.C., Sacharol, S. and Brody, A.L. (1985). Principles of package and development. (2nd edition), AVI, Vanstrand Reinhold Company: New York, 54-61.

[21] Maeda, E.E. and Mussa, D.M.D.N. (1986). The stability of vitamin $\mathrm{C}$ (L-Ascorbic Acid) in bottled and canned orange juice. Food Chemistry, 22: 51-58.

[22] Ndabikunze, B.K., Masambu, B.N. and Tiisekwa, B.M. (2010). Vitamin $\mathrm{C}$ and mineral contents, acceptability and shelf life of juice prepared from four indigenous fruits of the Miombo woodlands of Tanzania. Journal of Food and Agricultural Environment, 8: 91-96.

[23] AOAC. (2012). Official methods of analysis of AOAC International (19th ed.), Gaithersburg, M.D. USA.

[24] FAO (2008). Agriculture, Food and Nutrition for Africa, Rome, 385-387.

[25] Otta, K. (2000). Minimum shelf life of fruit juices. Flussings Abst. 51: 570-590.

[26] Jawaheer, B., Goburdhun, D. and Ruggoo, A. (2003). Effect of processing and storage of guava into jam and juice on the Ascorbic acid content. Plant Foods and Human Nutrition, 58: $1-12$.

[27] Orimaiye, D.O. (2001). Food analysis and therme fluid properties for food process engineers. Evanas - Emmdoor Int Pub; Lagos - Nigeria, 1.

[28] Alaka, O.O., Aina, J.O. and Falade, K.O. (2003). Effect of storage conditions on the chemical attributes of Ogbomoso mango juice. European Journal of Food Research and Technology, 218: 79-82. 
[29] Food and Agriculture Organization/World Health Organization (FAO/WHO) 2001. Human vitamin and mineral requirements. Report of a Joint FAO/WHO Expert Consultation.

[30] Polydera, A.C., Stoforos, N.G. and Taoukism, P.S. (2003). Comparative shelf life study and vitamin $\mathrm{C}$ loss kinetics in pasteurized and high pressure processed reconstituted orange juice. Journal of Food Engineering, 60: 21-29.

[31] Jalil, M.A., Javidullah, Y.D., Zeb, A. and Khan, M. (2004). Development of low caloric orange squash and physicochemical evaluation during its storage interval. Sarhad Journal of Agriculture, 20(4), 139-143.

[32] Kordylas, J.E. (1998). Processing and preservation of tropical and sub-tropical foods. ELBS. Hamshine.
[33] Ahmed, S.B. and Ramaswamy, S.A. (2004). Changes in tannin and cyanide content. Effect of traditional process. Food Chemistry, 86(2), 140-152.

[34] Ayhan, Z., Yeom, H.W., Zhang, Q.H. and Min, D.B. (2001). Flavour, colour and vitamin $\mathrm{C}$ retention of pulsed electric processed orange juice in different packaging materials. Journal of Agricultural Food Chemistry, 49(2), 667-674.

[35] Chechin, K.L. and Yamamoto, Y.H. (1998). Isolation, characterization and enzymic hydrolysis of pineapple sum. Journal of Food Science, 43, 1261-1264.

[36] Ihekoronye, I.A. and Ngoddy, P.O. (1985). Integrated Food Science and Technology for Tropics. Macmillian Publihers Limited, London, 303-303. 